\title{
Maltodextrin from Cassava Starch (Manihot Utilissima) and Its Application as Encapsulating Agent of Red Guava Juice Extract (Psidium Guajava)
}

\author{
Widya Krisnitya ${ }^{1}$, Purnama Darmadji ${ }^{1}$, Yudi Pranoto ${ }^{1}$ \\ ${ }^{1}$ Department of Food Technology and Agricultural Products, Faculty of Agricultural Technology, \\ Universitas Gadjah Mada, Yogyakarta, Indonesia \\ Corresponding Author: widya.krisnitya@gmail.com
}

ARTICLE INFO

Keywords:

Cassava starch

Maltodextrin

Encapsulation

Red guava

\section{ABSTRACT}

Cassava starch is one of the processed products of cassava, which can be made into maltodextrin. Maltodextrin is often applied to the encapsulation method of instant drink packaging in Indonesia. One of the most favorite fruits in the instant drink industry is red guava. The research objectives are to know the characteristic of maltodextrin made by hydrolysis of cassava starch, and to identify the effects of the amount of maltodextrin added to the characteristic of red guava extract produced. In the research, the hydrolysis time of cassava starch is varied into 60, 90, and 120 minutes. Maltodextrin made will be analyzed, and its characteristics on the encapsulation of red guava extract will be defined. The red guava juice is encapsulated by the variants of maltodextrin concentration as $10 \%, 15 \%, 20 \%$, and $25 \%$. Red guava extract powder produced from the selected amount of maltodextrin then be analyzed for its characteristics. The results showed that the highest DE was found in maltodextrin with 120 minutes hydrolysis time. The increased amount of maltodextrin added affects the increase of solubility and vitamin $\mathrm{C}$ levels of the produced red guava juice extract. The water content is not affected by the amount of maltodextrin added.

\section{INTRODUCTION}

Cassava is one of the bulbs that can be found easily in Indonesia. Cassava is also a local potential that can be explored to be a superior commodity. During this time, food processing with cassava as raw materials only produces products in the form of flour, starch, MOCAF (Modified Cassava Flour), and some traditional foods. Cassava starch can be processed into more valuable products, for example, to use it as a primary ingredient in maltodextrin production.

Maltodextrin is a compound made from partial hydrolysis of starch, consisting of a small number of sugar compounds in a simple form (mono- and disaccharides), relatively high amounts of short-chain oligosaccharides, and small amounts of long-chain oligosaccharides with DE values <20 and has no flavor (Blanchard and Katz, 1995). The 
process of the maltodextrin production method, which is commonly used, is the enzymatic method.

Encapsulation can be defined as a process in which thin membranes are formed around solid particles, liquid droplets, or gases that are fully filled in capsule walls (Barbosa-Canovas et al., 2005). In the encapsulation method, there is one crucial aspect related to capsule formation, which is an encapsulating agent. Encapsulating agent or coating or also called as the coating material is a membrane used to protect certain to-beencapsulated substances. Commonly used encapsulating agents are water-soluble carbohydrates, such as modified starches, gum acacia, maltodextrin, and solid corn syrup (Reineccius, G. A., 2002).

Red guava is one of the fruits that has become a favorite to be used in the instant drink industry in Indonesia. Red guava is a fruit that is rich in vitamin C. According to Anonymous (2011), vitamin C in red guava fruit is around $87 \mathrm{mg} / 100$ grams of red guava fruit. Vitamin $\mathrm{C}$ has beneficial functions for a body; it can play a role as an antioxidant, which can reduce the risk of cancer in a body. Vitamin $\mathrm{C}$ is also a vitamin that denatures and loses its function easily when exposed to high temperatures, oxygen, and light during food processing or storing (Alishahi, et al., 2010).

In the research, maltodextrin made of cassava starch will be used as an encapsulating agent of red guava juice. The use of maltodextrin as a coating material comes from several reasons, i.e., low cost, no effect on the flavor of the product, and the ability to protect flavor compounds from oxidation (Loksuwan, 2006).

\section{RESEARCH METHOD AND MATERIALS}

\subsection{Tools and Materials}

The main ingredients used in the research are cassava taken from Pasar Telo, Karangkajen, Yogyakarta, and red guava fruits taken from one of the supermarkets in Yogyakarta. Supporting materials used are alpha-amylase enzyme (produced by mesophyllic bacteria isolated from animal pancreas with optimal temperature specification of 80 to 85 degree of Celcius and $\mathrm{pH}$ of 6 to 7), solution of $\mathrm{CaCl}_{2} 200 \mathrm{ppm}$, $\mathrm{NaOH} 0,1 \mathrm{~N}$, and $\mathrm{HCl} 0,1 \mathrm{~N}$.

Tools used in the research are food processing mill Armfield, cabinet dryer, 60mesh-strainer, hot plate stirrer, $\mathrm{pH}$ meter Crison, blender (Miyako BL-101PL), centrifuge (Damon IIEC Division, IEC UV Centrifuge), spray dryer (Lab Plant SD-Basic), magnetic stirrer, extractor, and refractometer.

\subsection{Research Methods}

\subsubsection{Production of Cassava Starch}

The production process of cassava starch begins with the peeling of cassava bulbs from its outer skin, then grating, mixing with water as much as three times the weight of grated cassava, and pressing. From the pressing process, the filtrate was obtained and was left for 24 hours to get wet cassava starch. The wet cassava starch is then dried in a cabinet dryer at a temperature of $80^{\circ} \mathrm{C}$. Next, the dried cassava starch went through the grinding process and sieving process with the 60 -mesh-strainer. The fine-textured cassava starch will later be processed into maltodextrin.

\subsubsection{Maltodextrin Production}

Maltodextrin production from cassava starch is done by modifying the method of Chafid and Kusumawardhani (2010). First, the fine-textured cassava starch is mixed in $\mathrm{CaCl}_{2}$ solution as much as $0.1 \mathrm{~g} / \mathrm{ml}$. After that, the $\mathrm{pH}$ level of the solution is 
adjusted to 7 by adding $0.1 \mathrm{~N} \mathrm{NaOH}$ solution. Then, the alpha-amylase enzyme is added to the solution as much as $0.1 \%$ volume of the solution, followed by heating and stirring processes at $85^{\circ} \mathrm{C}$ for $60 ; 90$; and 120 minutes. After that, the solution is cooled down, and its $\mathrm{pH}$ level is adjusted again by adding $0.1 \mathrm{~N} \mathrm{HCl}$ until the $\mathrm{pH}$ becomes 3-4, followed by $0.1 \mathrm{~N} \mathrm{NaOH}$ until the $\mathrm{pH}$ became 4.5-6.5. After that, the maltodextrin is dried in a cabinet dryer at the temperature of $80^{\circ} \mathrm{C}$.

\subsubsection{Characterization of Maltodextrin Properties of Cassava Starch}

Maltodextrin produced then will be observed and analyzed based on its: dextrose equivalent (Lane and Eynon, 1966 in Loksuwan, 2006), water content (AOAC, 1984), and solubility (Loksuwan, 2006).

\subsubsection{Red Guava Juice Extract Powder Production}

In the red guava juice extract powder production, the fruit skin of red guava is included in the process. The next steps are weighing, washing, cutting, and blending processes. At the blending stage, the small-cuts of red guava fruit is mixed with water as much as the weight of the red guava. Then, the mixture filtering is filtered to get a puree of guava juice, or without the pulp. This purification is carried out again in the next stage, which is the centrifugation stage.

After the red guava juice supernatant is obtained, the maltodextrin is then mixed into the supernatant in varying concentrations. Variations in the amount of maltodextrin added are $10 \%, 15 \%, 20 \%$, and $25 \%$. Then, the encapsulation process of red guava juice using a spray dryer with the inlet temperature as $100^{\circ} \mathrm{C}$ is held. The red guava juice extract powder produced was then analyzed for its vitamin $\mathrm{C}$ levels by titration method using iodine (Sudarmadji et al., 2007).

\subsubsection{Characteristics of Red Guava Juice Extract Powder}

This stage aims to determine the characteristics of the red guava juice extract powder produced. Characterization parameters observed in the research are water content (AOAC, 1984), solubility (Loksuwan, 2006), and vitamin C levels (Sudarmadji et al., 2007).

\section{RESULT AND DISCUSSIONS}

\subsection{Maltodextrin Production}

In the production process of maltodextrin, an orientation is first performed to determine the starch hydrolysis time, which is able to produce the best dextrose equivalent (DE) but still in suitable DE range for maltodextrin. According to Blanchard and Katz (1995), maltodextrin is a compound made from partial hydrolysis of starch, consisting of a small number of sugar compounds in a simple form (mono- and disaccharides), relatively high amounts of short-chain oligosaccharides, and small amounts of long-chain oligosaccharides with DE values $<20$. Hydrolysis time variations used in the orientation of the manufacture of maltodextrin are 60, 90, and 120 minutes (Chafid and Kusumawardhani, 2010).

Based on Table 1, DE values of each maltodextrin with the variation of hydrolysis time can be seen. The longer the starch hydrolysis time taken, the DE value is higher as well. The lower the DE value was, the amount of reducing sugar produced is also lower. In addition, the higher the DE value, the amount of sugar with low molecular weight is also higher. Low molecular weight sugar can act as a plasticizer to prevent shrinkage during the drying process (Loksuwan, 2006). Based on this theory, the hydrolysis time chosen is 120 minutes, which resulted in a DE value of 16.53. The 
DE value in maltodextrin produced after 120 minutes is in the suitable range of DE maltodextrin values. Moreover, the high DE value can role in preventing shrinkage of the capsule's surface during the drying process.

Table 1. Dextrose equivalent (DE) values of maltodextrin produced in 60, 90, dan 120 minutes of hydrolysis time.

\begin{tabular}{ccc}
\hline Samples & Hydrolysis time (min) & Dextrose Equivalent \\
\hline Maltodextrin of & 60 & 9.94 \\
cassava starch & 90 & 12.25 \\
& 120 & 16.53 \\
\hline
\end{tabular}

\subsection{Characterization of Maltodextrin Properties of Cassava Starch}

Solubility is a percentage of the amount of maltodextrin from cassava starch to dissolve in water. The higher the solubility percentage of maltodextrin, the better the nature of maltodextrin as an encapsulating agent is, since it can dissolve the red guava juice extract powder well. Based on the experiment results, the solubility of maltodextrin made of cassava starch is $80.08 \%$. Solubility is also affected by several things, such as particle size and the DE value. The higher the DE value is, the smaller the size of break down molecules of the starch is. Hence, the amount of components that dissolve in water will be even higher (Loksuwan, 2006).

Table 2. Characteristics of maltodextrin made of cassava starch.

\begin{tabular}{cc}
\hline Parameter & Result \\
\hline Sollubility $(\%)$ & 80.08 \\
Dextrose Equivalent & 17.08 \\
Water content $(\%)$ & 3.12 \\
\hline
\end{tabular}

The DE value is a measure of the starch molecules' degree of hydrolysis, which is related to the amount of reducing sugar production. The higher the DE value, the more the reducing sugar produced. Moreover, the higher the DE value, the higher the plasticity and solubility of the substance are. High plasticity properties will prevent capsule shrinkage during the drying process (Loksuwan, 2006). According to the experiment results, the DE value of maltodextrin made of cassava starch is 17.08. The result is still in terms of DE value in maltodextrin, according to Blanchard and Katz (1995), which is $<20$.

Water content is the amount of water contained compared to the weight of the material. The water content will affect the expiration date and the hygroscopic nature of maltodextrin. Based on the experiment results, the water content of maltodextrin is $3.12 \%$. It supports the required characteristics of maltodextrin stated by Blanchard and Katz (1995) in Chafid and Kusumawardhani (2010) that the maximum maltodextrin water content is $6 \%$.

\subsection{Effect of Variation in the Maltodextrin to Vitamin C Levels of Red Guava Fruit Extract Powder}

The oriented amount variations of maltodextrin added are $10 \%, 15 \%, 20 \%$, and $25 \%$. The variations are chosen because according to Kha, et al. (2010), the ratio of the addition of maltodextrin to the encapsulation process depends on the DE maltodextrin itself and the encapsulated sample. Samples taken in the research are the red guava juice with maltodextrin, which has DE value above 10 . The use of maltodextrin 
concentrations below $10 \%$ makes the produced powder too thick and is sticky to the walls of the encapsulation device. However, the use of maltodextrin concentration above $30 \%$ makes the powder lose the original color of the encapsulated material.

Table 3. Vitamin $\mathrm{C}$ levels of red guava juice extract with various maltodextrin concentrations.

\begin{tabular}{ccc}
\hline Sample & \multicolumn{2}{c}{ Vitamin C Level $(\mathrm{mg} / 100 \mathrm{~g})$} \\
\cline { 2 - 3 } & $\mathrm{wb}$ & $\mathrm{db}$ \\
\hline $\begin{array}{c}\text { Red Guava Juice Extract }+ \\
\text { 10\% Maltodextrin }\end{array}$ & 779.70 & 814.56 \\
$\begin{array}{c}\text { Red Guava Juice Extract }+ \\
\text { 15\% Maltodextrin }\end{array}$ & 917.48 & 963.33 \\
$\begin{array}{c}\text { Red Guava Juice Extract }+ \\
\text { 20\% Maltodextrin }\end{array}$ & 1140.27 & 1189.64 \\
$\begin{array}{c}\text { Red Guava Juice Extract }+ \\
\text { 25\% Maltodextrin }\end{array}$ & 1155.96 & 1207.14 \\
\hline
\end{tabular}

Based on Table 3, the analysis result of vitamin $\mathrm{C}$ levels in red guava juice extract powder with variations of maltodextrin added as $10 \%, 15 \%, 20 \%$, and $25 \%$ can be seen. The higher the amount of maltodextrin is added, the vitamin $\mathrm{C}$ levels contained in the red guava juice extract powder will increase. However, the increase in vitamin $\mathrm{C}$ levels is no longer significant at the addition of $25 \%$ maltodextrin.

\subsection{Effect of Variation on the Maltodextrin to the Characteristics of Red Guava Fruit Extract Powder}

Based on the experiment results, as shown in Table 4, the water content of red guava powder made by the addition of $10 \%$ maltodextrin is $4.28 \%, 15 \%$ maltodextrin is $4.76 \%$, and $20 \%$ maltodextrin is $4.15 \%$. Then, a statistical test was carried out with $p$ $<0.05 \%$. Statistical test results showed that the water content of guava powder was insignificantly different for all samples with different amounts of added maltodextrin. This is caused by the same drying treatment among samples, which is by a spray dryer with an inlet temperature of $100^{\circ} \mathrm{C}$ and an outlet temperature of $50^{\circ} \mathrm{C}$.

The solubility of red guava juice extract made with the addition of $10 \%$ maltodextrin is $60.01 \%$, $15 \%$ maltodextrin is $88.46 \%$, and $20 \%$ maltodextrin is $93.58 \%$ (Table 4). It indicates that the solubility rate is increased along with the addition of the amount of maltodextrin in red guava juice. Based on the statistical analysis with $p$ $<0.05 \%$ test results, there was a significant difference between the solubility of red guava juice powder made with the variants of maltodextrin concentrations as $10 \%$, $15 \%$, and $20 \%$. However, there was no significant difference in the sample of red guava juice extract made with the addition of $15 \%$ maltodextrin with red guava juice extract made with the addition of $20 \%$ maltodextrin. This may happen due to the relatively similar particle size. Particle size affects the solubility of a sample. The smaller the particle size is, the more particles that can dissolve in water.

The level of vitamin $\mathrm{C}(\% \mathrm{db})$ in red guava juice powder made with the addition of $10 \%$ maltodextrin is $883.33 \%, 15 \%$ maltodextrin is $1076.05 \%, 20 \%$ maltodextrin is $1371.99 \%$. Based on these results, the higher the amount of maltodextrin added, the 
higher the vitamin $\mathrm{C}$ level of red guava juice powder is. Based on statistical analysis with $\mathrm{p}<0.05 \%$ test results, the red guava juice powder made with the addition of $10 \%$, $15 \%$, and $20 \%$ maltodextrin were all significantly different in terms of vitamin C level. This is because the more maltodextrin is added, the more protected and encapsulated vitamin $C$ is. Vice versa, the less coating material used, then the encapsulated vitamin $C$ will be less because there is less material that can protect the vitamin $\mathrm{C}$ from heat damage.

Table 4. Characteristics of red guava juice extract powder with various amount of maltodextrin.

\begin{tabular}{|c|c|c|c|c|}
\hline \multirow{2}{*}{ Sample } & \multirow{2}{*}{$\begin{array}{c}\text { Water } \\
\text { content } \\
(\%)\end{array}$} & \multirow[t]{2}{*}{$\begin{array}{l}\text { Solubility } \\
\quad(\%)\end{array}$} & \multicolumn{2}{|c|}{$\begin{array}{l}\text { Vitamin C Level } \\
(\mathrm{mg} / 100 \mathrm{~g})\end{array}$} \\
\hline & & & $w b$ & $\mathrm{Db}$ \\
\hline $\begin{array}{c}\text { Red Guava Juice Extract + } \\
10 \% \text { Maltodextrin }\end{array}$ & $4.28^{\mathrm{a}}$ & $60.01^{\mathrm{a}}$ & 845.52 & $883.33^{\mathrm{a}}$ \\
\hline $\begin{array}{c}\text { Red Guava Juice Extract + } \\
15 \% \text { Maltodextrin }\end{array}$ & $4.76^{\mathrm{a}}$ & $88.46^{\mathrm{b}}$ & 1024.83 & $1076.05^{b}$ \\
\hline $\begin{array}{c}\text { Red Guava Juice Extract + } \\
20 \% \text { Maltodextrin }\end{array}$ & $4.15^{\mathrm{a}}$ & $93.58^{\mathrm{b}}$ & 1260.48 & $1371.99^{c}$ \\
\hline
\end{tabular}

\section{CONCLUSIONS}

Based on the conducted research experiments, it can be concluded that the best starch hydrolysis time is at 120 minutes, which results in the optimal DE value. The higher the amount of maltodextrin added, the solubility and vitamin $\mathrm{C}$ content of the guava juice powder extract will increase as well.

\section{BIBLIOGRAPHY}

Alishahi, A., Mirvaghefi, A., Tehrani, M. R., Farahmand, H., Shojaosadati, S. A., Dorkoosh, F. A., dan Elsabee, M. Z. (2010). Shelf Life and Delivery Enhancement of Vitamin C Using Chitosan Nanoparticles. Food Chemistry. Volume 126, 935-940.

Anonymous. (2011). DKBM Indonesia. http://suyatno.blog.undip.ac.id/files/2010/04/DKBMIndonesia.pdf. Accessed on June 162012 at 20.40 WIB.

AOAC. (1984). Official Methods of Analysis. Washington: Association of Official Analytical Chemists.

Barbosa-Canovas, G., Ortega-Rivas, E., Juliano, P., dan Yan, H. (2005). Food Powders:Physical Properties, Processing, and Functionality. New York: Plenum Publisher.

Blancard, P. H. dan Katz, F. R. (1995). Starch Hydrolysates in Food Polysaccharides and Their Aplication. New York: Marcel Dekker, Inc.

Chafid, A. dan Kusumawardhani, G. (2010). Modifikasi Tepung Sagu Menjadi Maltodekstrin Menggunakan Enzim $\alpha$-amylase. Skripsi. Fakultas Teknik. Universitas Diponegoro Semarang. 
Kha, T. C., Nguyen, M. H., dan Roach, P. D. (2010). Effects of Spray Drying Conditions on The Physicochemical and Antioxidant Properties of The Gac (Momordica cochinchinensis) Fruit Aril Powder. Journal of Food Engineering. Volume 98, 385392.

Loksuwan, J. (2006). Characteristics of Microencapsulated $\beta$-carotene Formed by Spray Drying with Modified Tapioca Starch, Native Tapioca Starch and Maltodextrin. Food Hydrocolloids. Volume 21. 928-935.

Reineccius, G. A. (2002). Flavor Encapsulation in Edible Coatings and Films to Improve Food Quality. New York: CRC Press.

Sudarmadji, S., Haryono, B., and Suhardi. (2007). Analisa Bahan Makanan dan Pertanian. Yogyakarta:Penerbit Liberty. 


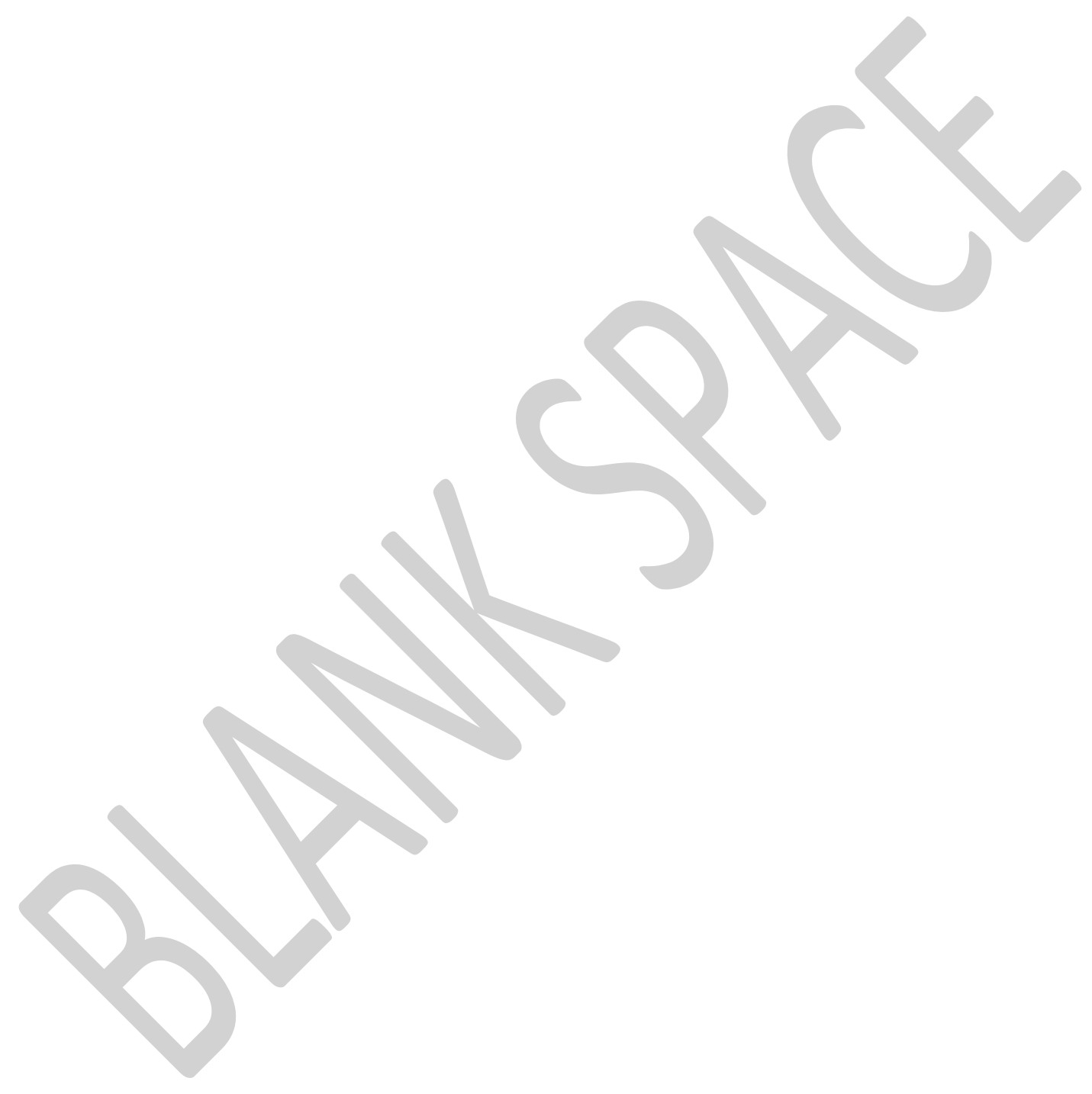

